\title{
Jurnal Bidang Pendidikan Dasar
}

Vol 4 No 2, Juni 2020, pp 155 - 163

Available at:

http://ejournal.unikama.ac.id/index.php/JBPD

JBPD

\section{Meningkatan Hasil Belajar Siswa Menggunakan Realistic Mathematics Education (RME) \\ Berbantuan Media Konkrit}

\author{
Dedy Setyawan \\ Universitas Muhammadiyah Palangkaraya \\ Dedy_blackdemon@yahoo.com
}

\begin{abstract}
This study aims to improve the activity and student learning outcomes in mathematics in calculating the volume of a cube by using the Realistic Mathematics Education (RME) model assisted by concrete media. This type of research is Classroom Action Research (CAR). The subjects of this study were $5^{\text {th }}$ grade students of Muhammadiyah Pahandut Palangka Raya Elementary School, totaling 19 people. The sampling technique used is saturated sampling. Data collection techniques using observation and tests. The main results of this study indicate that the learning activities of students when learning mathematics material calculates the volume of the cube using the RME model assisted by concrete media shows the final test results of cycle 1 with $73.68 \%$ and the final test results in cycle 2 to $100 \%$ and are in very good criteria. It is proven that by using the RME model which is assisted by concrete media can increase student mathematics learning activities and outcomes.
\end{abstract}

Keywords: Learning Outcomes, Mathematics, Cube Volume, Realistic Mathematics Education (RME) Model, Concrete Media.

\begin{abstract}
Abstrak. Penelitian ini bertujuan untuk meningkatkan aktivitas dan hasil belajar matematika siswa dalam menghitung volume kubus dengan menggunakan model Realistic Mathematics Education (RME) berbantuan media konkret. Jenis penelitian yang digunakan adalah Penelitian Tindakan Kelas (PTK). Subjek penelitian ini adalah siswa kelas V SDS Muhammadiyah Pahandut Palangka Raya yang berjumlah 19 orang. Teknik pengambilan sampel yang digunakan adalah sampling jenuh. Teknik pengumpulan data menggunakan observasi dan tes. Hasil utama penelitian ini menunjukan bahwa Aktivitas belajar siswa pada saat pembelajaran Matematika materi menghitung volume kubus dengan menggunakan model Realistic Mathematics Education (RME) berbantuan media konkret di kelas $\mathrm{V}$ SDS Muhammadiyah Pahandut Palangka Raya menunjukkan hasil tes akhir siklus 1 dengan 73,68\% dan hasil tes akhir pada siklus 2 menjadi 100\% dan berada pada kriteria sangat baik. Terbukti bahwa dengan menggunakan model Realistic Mathematics Education (RME) berbantuan media konkrit dapat meningkatkan aktivitas dan hasil belajar matematika siswa.
\end{abstract}

Kata Kunci : Hasil Belajar, Matematika, Volume Kubus, Model Realistic Mathematics Education (RME), Media Konkret.

\section{Pendahuluan}

Pendidikan adalah salah satu sektor yang paling penting dalam pembangunan nasional. Pendidikan bagi bangsa Indonesia merupakan kebutuhan mutlak. Pendidikan juga menjadi andalan utama dalam upaya meningkatkan kualitas hidup manusia, dalam pendidikan penting untuk mewujudkan suasana belajar dan proses pembelajaran yang baik, 
agar peserta didik secara aktif mengembangkan potensinya sehingga peserta didik dapat memperoleh pengetahuan, pemahaman dan perubahan tingkah laku. Penyelenggaraan pendidikan tersebut diawali dari jenjang pendidikan dasar. Pendidikan Dasar merupakan jenjang pendidikan yang melandasi pendidikan menengah, sehingga tonggak awal mula pemahaman siswa tergantung dari bagaimana penyampaian guru di kelas khususnya pada materi pelajaran yang dianggap sulit oleh siswa seperti bidang sains khususnya matematika.

Mata pelajaran matematika di sekolah dasar merupakan salah satu program pengajaran yang bertujuan untuk mempersiapkan peserta didik agar sanggup menghadapi perubahan keadaan didalam kehidupan yang selalu berkembang, melalui latihan bertindak atas dasar pemikiran secara logis, rasional, kritis, cermat, jujur dan efektif dan juga mempersiapkan peserta didik agar menggunakan matematika dan pola pikir matematika dalam kehidupan sehari-hari dan mempelajari berbagai ilmu pengetahuan. Matematika berfungsi untuk mengembangkan kemampuan menghitung, mengukur, menurunkan dan menggunakan rumus matematika sederhana yang diperlukan dalam kehidupan sehari-hari.

Beberapa hasil penelitian menunjukkan bahwa pembelajaran matematika khususnya pada materi bangun ruang masih menjadi momok bagi siswa. Penelitian dari Kurino (2017) menunjukkan bahwa permasalahan yang terjadi pada siswa kelas $\mathrm{V}$ pada materi bangun ruang di SDN Cijati Majalengka memerlukan 3 siklus untuk bisa melewati standar KKM. Hal ini membuktikan bahwa mata pelajaran matematika pada materi bangun ruang juga menjadi permasalahan di kota lain. Hasil observasi dari penelitian Rostika (2008) menunjukkan adanya kejenuhan belajar yang dialami siswa pada pembelajaran matematika khususnya materi bangun ruang karena pembelajaran yang monoton dan kurang menarik. Berdasarkan hasil penelitian tersebut, maka dibutuhkan solusi berupa penerapan model pembelajaran.

Model pembelajaran menurut Bruce Joyce dan Weil (Dermawan dan Wahyudin, 2018 : 1) "model pembelajaran adalah suatu rencana atau pola yang dapat digunakan membentuk kurikulum (rencana pembelajaran jangka panjang) merancang bahan-bahan pembelajaran, dan membimbing pembelajaran di kelas atau yang lain". Selain itu, menurut Agus Suprijono (2011: 45) "model pembelajaran adalah pola yang digunakan sebagai pedoman dalam merencanakan pembelajaran di kelas maupun tutorial.

Salah satu model pembelajaran yang dapat membantu guru di kelas dalam mentransfer materi matematika kepada siswa khususnya materi bangun ruang adalah model pembelajaran Realistic Mathematic Education (RME). Menurut Turmudi (Sumantri, 2015 :108) Realistic Mathematic Education (RME) yang dalam makna Indonesia berarti Pendidikan Matematika Realistik (PMR) dikembangkan berdasarkan pemikiran Hans Freundenthal yang berpendapat matematika berpendapat merupakan aktivitas insani (human activities) dan harus dikaitkan dengan realita. Sedangkan menurut Achmad (34: 2011) model pembelajaran Realistic Mathematic Education (RME) merupakan salah satu alternatif pembelajaran yang menuntut peserta didik untuk mengkontruksikan pengetahuan dengan kemampuannya sendiri melalui aktivitas yang dilakukannya dalam kegiatan pembelajaran. 
Adapun Langkah-langkah model pembelajaran Realistic Mathematic Education (RME) menurut Shoimin (2014) adalah sebagai berikut:

1). Memahami masalah konstekstual.

Guru memberikan masalah (soal) kontekstual dan peserta didik diminta untuk memahami masalah tersebut. Guru menjelaskan soal atau masalah dengan memberikan petunjuk atau saran seperlunya (terbatas) terhadap bagian-bagian tertentu yang dipahami peserta didik,

2). Menyelesaikan masalah kontekstual. Peserta didik secara individu disuruh menyelesaikan masalah kontekstual pada buku peserta didik atau LKPD dengan cara tersendiri. Cara penyelesaian dan pemecahan masalah yang berbeda lebih diutamakan. Guru memotivasi peserta didik untuk menyelesaikan masalah tersebut dengan memberikan pertanyaan-pertanyaan penuntun untuk mengarahkan siswa memperoleh penyelesaian soal. Misalnya : bagaimana kamu tahu itu, bagaimana caranya, mengapa kamu berpikir seperti itu dan lain-lain. Disamping itu pada tahap ini siswa diarahkan untuk membentuk dan menggunakan model sendiri untuk membentuk dan menggunakannya guna memudahkan menyelesaikan masalah (soal),

3). Membandingkan dan mendiskusikan jawaban. Peserta didik diminta untuk membandingkan jawaban dan mendiskusikan jawaban mereka dalam kelompok kecil. Setelah itu, hasil dari diskusi dibandingkan pada diskusi kelas yang dipimpin oleh guru. Pada tahap ini dapat digunakan siswa untuk melatih keberanian mengemukakan pendapat, meskipun berbeda dengan teman lain atau bahkan dengan gurunya.

4). Menarik kesimpulan. Berdasarkan hasil diskusi kelompok dan diskusi kelas yang dilakukan, guru mengarahkan siswa untuk menarik kesimpulan tentang konsep, definisi teorema, prinsip atau prosedur matematika yang terkait dengan masalah kontekstual yang baru diselesaikan.

Beberapa kelebihan Realistic Mathematic Education (RME) diantaranya pembelajaran matematika realistik memberikan pengertian yang jelas kepada peserta didik tentang kehidupan sehari-hari dan kegunaan pada umumnya bagi manusia, pembelajaran matematika realistik memberikan pengertian yang jelas kepada peserta didik bahwa matematika adalah suatu bidang kajian yang dikonstruksikan dan dikembangkan sendiri oleh peserta didik, tidak hanya oleh mereka yang disebut pakar dalam bidang tersebut, pembelajaran matematika realistik memberikan pengertian yang jelas kepada peserta didik cara penyelesaian suatu soal atau masalah tidak harus tunggal dan tidak harus sama antara yang satu dengan yang lain. Setiap orang bisa menemukan dan menggunakan cara sendiri, asalkan orang itu sungguh-sungguh dalam mengerjakan soal atau masalah tersebut, pembelajaran matematika raelistik memberikan pengertian yang jelas kepada peserta didik bahwa dalam mempelajari matematika, proses pembelajaran merupakan suatu yang utama dan orang harus menjalani proses tersebut dan berusaha untuk menemukan sendiri konsepkonsep matematika dengan bantuan pihak yang lain yang lebih mengetahui (misalkan guru).

Observasi yang dilakukan di SDS Muhammadiyah Pahandut Palangka Raya, terkait implementasi model pembelajaran yang dilakukan oleh guru mata pelajaran Matematika adalah masih cenderung menggunakan model pembelajaran konvensional dengan metode 
ceramah. metode tersebut merupakan proses pemberian ilmu (tranfer of knowledge) yang dilakukan secara verbal dan penjelasan konsep yang dilakukan hanya secara lisan dengan tulisan yang ditulis di papan tulis. Keaktifan peserta didik dalam proses pembelajaran menjadi rendah atau menjadi pasif dan hanya menunggu apa yang diberikan oleh guru. Peserta didik kurang semangat untuk lebih serius mempelajari matematika. Peserta didik sulit untuk memahami rumus, peserta didik hanya ingin belajar dan mengerjakan tugas bersama atau berpasangan dengan temannya. Hasil belajar peserta didik juga belum mencapai KKM, perlu beberapa kali pengulangan materi agar bisa melewati KKM yang ditentukan.

Merujuk pada hasil observasi yang dilakukan, maka penting untuk diterapkan model RME dengan berbantuan media konkrit khususnya pada bangun ruang siswa kelas $V$ SD untuk mengatasi kejenuhan siswa dan memudahkan siswa dalam memahami materi bangun ruang karena terlibat langsung secara visual dan fisik dalam pembelajaran sehingga dapat meningkatkan hasil belajar matematika siswa di SDS Muhammadiyah Pahandut Palangka Raya.

Beberapa penelitian telah menerapkan pembelajaran menggunakan model RME diantaranya Nugroho (2018) menerapkan RME pada pembelajaran matematika di SMK, Soraya, Yurniwati dan Cahyana (2018) yang menerapkan RME pada pembelajaran matematika di SD. Selanjutnya Gusnarsi, Utami dan Wahyuni (2017); Noviyana dan Fitriani (2018); Rosyada, sari dan Cahyaningtas (2019) telah menerapkan dan mencoba mengetahui pengaruh RME dalam proses pembelajaran. Berdasarkan penelitian yang ada diketahui penerapan RME yang telah dilakukan tidak menggunakan beberapa bantuan media. Pada penelitian ini mencoba untuk menggunakan bantuan media kongkrit pada materi menghitung kubus. Penggunaan media kongkrot ini diharapkan mampu mengembangkan pemahaman siswa lebih nyata dan bermakna.

Menurut Suparman (Fathurrohman dan Sutikno, 2014 :65) "media merupakan alat yang digunakan untuk menyalurkan pesan atau informasi dari pengirim kepada penerima". Adapula menurut Miarso (Sumatri, 2015: 303) menyatakan bahwa "media adalah segala suatu yang dapat merangsang terjadinya proses belajar dalam diri peserta didik. Menurut Asyhar (diky dkk : 2019) yang menyatakan bahwa, "benda realita atau benda nyata adalah benda yang dapat dilihat, didengar, atau dialami oleh siswa sehingga memberikan pengalaman langsung kepada mereka". Menurut Sanaky (2011:50) "media konret yaitu benda nyata yang dapat dihadirkan diruang untuk keperluan proses pembelajaran". Sehinga dapat disimpulkan bahwa media konkrit merupakan media nyata yang dapat dilihat, didengar dan dapat dihadirkan untuk keperluan proses pembelajaran. Media konkrit yang digunakan dalam penelitian ini adalah menggunakan media kubus satuan untuk menghitung volume kubus.

Penelitian ini berfokus pada penggunaan model pembelajaran Realistic Mathematic Education (RME) berbantuan media konkrit yakni menggunakan media kubus satuan pada materi bangun ruang menghitung volume kubus untuk meningkatkan hasil belajar matematika siswa kelas V SDS Muhammadiyah Pahandut Palangka Raya. 


\section{Metode}

Jenis penelitian ini adalah Penelitian Tindakan Kelas (PTK). Penelitian tindakan kelas diartikan sebagai upaya atau tindakan yang dilakukan oleh guru atau peneliti untuk memecahkan masalah pembelajaran melalui penelitian (Diplan dan Setiawan, 2018 :14). PTK dilaksanakan dengan 4 kegiatan utama, atau tahapan yaitu Plan (perencanaan), Action (tindakan), Observation (pengamatan), dan Reflection (refleksi) (S \& Taggart, 1992). Penelitian ini dilaksanakan di bulan November sampai dengan Maret tahun pelajaran 2019/2020 di SDS Muhammadiyah Pahandut Palangka Raya yang terletak di Jalan Rasak atau Jl. Ulin. Pengambilan sampel dilakukan dengan teknik sampling jenuh. Subjek penelitian adalah seluruh siswa kelas V SDS Muhammadiyah Pahandut Palangka Raya yang berjumlah 19 siwa terdiri dari 12 siswa laki-laki dan 7 siswa perempuan dengan rincian sebagai berikut.

Tabel 1. Subjek Penelitian

\begin{tabular}{ccc}
\hline No & Jenis Kelamin Peserta Didik & Jumlah Peserta Didik \\
\hline 1 & Laki-laki & 12 Orang \\
\hline 2 & Perempuan & 7 Oang \\
\hline & Jumlah Keseluruhan & 19 Orang \\
\hline
\end{tabular}

Sumber: Data Guru Kelas V SDS Muhammadiyah Pahandut Palangka Raya

Pengumpulan data yang digunakan adalah obsevasi dan tes. Tes digunakan untuk memperoleh data kuantitatif, sedangkan observasi untuk memperoleh data kualitatif. Data kualitatif diproleh dari aktivitas peneliti dan aktivitas peserta didik selama proses kegiatan belajar mengajar dengan penerapan teknik pembelajaran. Data kuantitatif berasal dari tes awal yang dilakukan pada awal pertemuan dan tes akhir bertujuan untuk melihat hasil belajar peserta didik.

Tabel 2. Rekapitulasi Data Observasi Aktivitas Peserta Didik

\begin{tabular}{cccc}
\hline & Jumlah Skor & Skor Rata-rata & Kategori \\
\hline Siklus I & 64 & 3,04 & Baik \\
\hline Siklus II & 80 & 3,8 & Sangat Baik \\
\hline
\end{tabular}

\section{Hasil Dan Pembahasan}

Penelitian Tindakan Kelas (PTK) dilaksanakan dengan 4 tahap kegiatan, yaitu Plan (perencanaan), Action (tindakan), Observation (pengamatan), dan Reflection (refleksi) (S \& Taggart, 1992). Hasil observasi awal yang dilakukan kepada siswa ditampilkan pada gambar 1.

Gambar 1 menunjukkan bahwa aktivitas peserta didik meningkat pada setiap siklus. Pada siklus I skor yang diperoleh peserta didik adalah 64,5 dengan rata-rata 3,07 dan persentase $76,78 \%$ sedangkan pada siklus II skor yang diperoleh peserta didik adalah 79 dengan rata-rata 3,75 dengan persentase $94,04 \%$. Hal ini menunjukkan bahwa dengan menggunakan model Realistic Mathematics Education (RME) berbantuan media konkret sangat baik. 


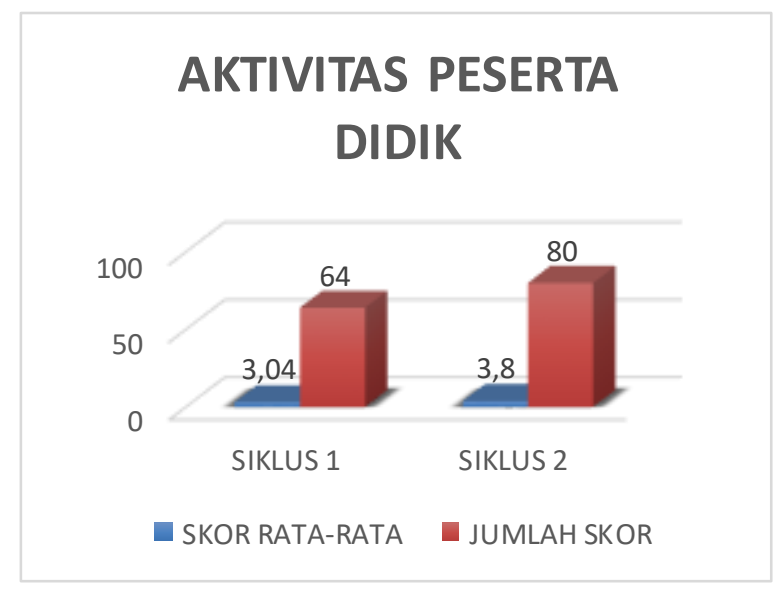

Gambar 1 Aktivitas Peserta Didik

Hasil belajar dengan teknis tes yang dilakukan sebelum perlakuan dan sesudah perlakuan dengan menggunakan model RME berbantuan media konkrit disajikan pada tabel 3.

Tabel 3. Hasil Belajar Peserta Didik Pada Tes Awal dan Tes Akhir

\begin{tabular}{cccc}
\hline No & Data & $\begin{array}{c}\text { Persentase Ketuntasan } \\
\text { Klasikal }\end{array}$ & Nilai Rata-rata \\
\hline 1 & Observasi Awal & $42,10 \%$ & 57,36 \\
\hline 2 & Tes Akhir Siklus I & $73,68 \%$ & 72,10 \\
\hline 3 & Tes Akhir Siklus II & $100 \%$ & 83,15 \\
\hline
\end{tabular}

Dari table 3 dapat diketahui bahwa pada tes awal persentase ketuntasan klasikal peserta didik hanya mencapai $47,36 \%$ dengan kategori tidak tercapai, siklus I persentase ketuntasan klasikal mencapai $73,68 \%$ dengan nilai rata-rata 72,10 kategori tidak tercapai, siklus II ketuntasan klasikal meningkat hingga mencapai 100\% kategori tercapai dengan nilai rata-rata 83,15. Berdasarkan hasil model Realistic Mathematics Education (RME) berbantuan media konkret pada mata pelajaran matematika dengan materi menghitung volume kubus bangun ruang dapat meningkatkan hasil belajar peserta didik.

Hasil observasi dan tes dari sampel penelitian dengan 2 siklus menunjukkan hasil yang baik. Tahap pertama pada pembelajaran RME adalah memotivasi siswa, dengan kata lain memusatkan fokus siswa sebelum mengikuti pelajaran. Peneliti menggunakan teknik ice breaking sebelum memulai pelajaran dengan menggunakan model RME berbantuan benda konkrit, baik pada saat memulai siklus 1 ataupun siklus 2. Penyampaian tujuan pembelajaran secara jelas juga menjadi poin penting yang tidak terlewatkan. Pada saat proses pembelajaran berlangsung siswa dapat mengkonstruksi pengetahuannya sendiri dengan bimbingan guru sehingga membantu siswa untuk memahami keterkaitan matematika dengan kehidupan sehari-hari dan kegunaannya karena proses pembelajaran merupakan suatu yang utama bagi siswa untuk memperoleh pengalaman secara pribadi terhadap konsep-konsep matematika dengan bantuan guru. Tanpa kemauan dari diri sendiri untuk menjalani dan memahami proses tersebut, pembelajaran bermakna yang disampaikan guru tidak akan tercapai. 
Model pembelajaran RME berbantuan media konkrit sangat membantu siswa dalam memahami materi bangun ruang volume kubus karena pada saat proses penyampaian materi berlangsung, guru memfasilitasi siswa untuk mengajukan masalah yang riil bagi siswa sesuai dengan pengalaman dan tingkat pengetahuannya serta melihat secara langsung (visual) benda berbentuk kubus secara nyata, sehingga siswa dapat terlibat aktif dalam pembelajaran yang bermakna. Keberhasilan pembelajaran dapat terlihat dari hasil tes akhir pada siklus 1 dan 2 yang mengalami peningkatan. Hasil tes akhir siklus 1 dengan 73,68\% menjadi $100 \%$ pada tes akhir siklus tahap 2. Hasil tersebut membuktikan bahwa tejadi peningkatan hasil belajar matematika siswa kelas V SDS Muhammadiyah Pahandut Palangka Raya pada materi bangun ruang menghitung volume kubus dengan menggunakan model RME berbantuan media konkrit.

Penerapan model RME dapat membantu siswa memahami materi pelajaran matematika. Sari (2015) menjelaskan bahwa penerapan model RME dengan media konkret dapat meningkatkan pemahaman siswa pada materi pecahan, meningkatkan kemampuan dalam memecahkan masalah (Rosyada et.al, 2019; Noviyana \& Fitriani, 2018), Meningkatkan kemampuan dalam menalar (Gusnarsi \& Wahyuni, 2017), meningkatkan motivasi dan prestasi belajar siswa (Nugroho \& Kendal, 2018), Berpikir kreatif (Soraya, Cahyana \& Yurniwati, 2018), meningkatkan hasil belajar matematika siswa (Mariani, 2014), dan dapat dijadikan salah satu model alternatif pembelajaran matematika sekolah agar dapat membantu siswa dalam memahami materi matematika dan mendapatkan hasil yang baik (Seri Ningsih, 2014).

\section{Kesimpulan}

Berdasarkan hasil penelitian dari siklus 1 dan siklus 2 mengenai model pembelajaran RME berbantuan media konkrit pada materi bangun ruang volume kubus di SDS Muhammadiyah Pahandut Palangka Raya dapat disimpulkan bahwa aktivitas belajar siswa pada pembelajaran matematika materi menghitung volume kubus (bangun ruang) dengan menggunakan model Realistic Mathematics Education (RME) berbantuan media konkret dengan kriteria sangat baik. Selain itu pula, model Realistic Mathematics Education (RME) berbantuan media konkret meningkatkan hasil belajar matematika pada materi menghitung volume kubus. Penelitian ini berimplikasi kepada antusiasnya peserta didik saat diterapkannya model RME berbantuan media konkret dan ketertarikan guru untuk mencoba model RME di bab materi pelajaran matematika yang lain.

\section{Daftar Rujukan}

Dermawan, D. \& Wahyudin, D. (2018). Model Pembelajaran Di Sekolah. Bandung: PT Remaja Rosdakarya.

Diplan, Setiawan, M. A. (2018). Penelitian Tindakan Kelas Teori Serta Panduan Bagi Guru Kelas dan Guru Bimbingan Konseling. Yogyakarta: CV Budi Utama. 
Fathurrohman, P., Sutikno, S. (2014). Strategi Belajar Mengajar: Strategi Mewujudkan Pembelajaran Bermakna Melalui Pemahaman Konsep Umum dan Islami. Bandung: PT Refika Aditama.From http://jurnal.unma.ac.id/index.php/CP/article/view/594/557 From https://jurnal.uns.ac.id/jkc/article/view/40677/26806

Gusnarsi, D., Utami, C., \& Wahyuni, R. (2017). Pengaruh Model Pembelajaran Realistic Mathematics Education ( RME ) Terhadap Kemampuan Penalaran Matematis Siswa Pada Materi Lingkaran Kelas VIII. Jurnal Pendidikan Matematika Indonesia, 2(1), 32-36. Irmansyah, A. (2011). Efektivitas Pembelajaran Matematika Melalui Model Pembelajaran Realistics Education (RME) Terhadap Peningkatan Pemahaman Konsep Matematika Siswa SD. Jurnal Pendidikan, 12(1): $33-40$.

Jennah, R. (2009). Media Pembelajaran. Banjarmasin: Antasari Press.

Kurino, Y. D. (2017). Penerapan Realistic Mathematic Education Dalam Meningkatkan Hasil Belajar Siswa Kelas V Pada Materi Volume Bangun Ruang di Sekolah Dasar. Jurnal Cakrawala Pendas, 3(2) 2579-4442.

Mariani, Ni Nym, Suardika, I Wy Rinda, Manuaba, I. B. S. (2014). Pengaruh Pendekatan Realistic Mathematics Education Berbantuan Media Konkret Terhadap Hasil Belajar Matematika Siswa Kelas V SD. Mimbar PGSD, 2(1).

Noviyana, H., \& Fitriani, D. (2018). Pengaruh Model Realistic Mathematics Education (RME) Terhadap Kemampuan Pemecahan Masalah Matematis Siswa Kelas VIII SMP. Prosiding Seminar Nasional Matematika Dan Pendidikan Matematika UIN Raden Intan Lampung, 385-392.

Ningsih, S., (2014). Realistic Mathematics Education: Model Alternatif Pembelajaran Matematika Sekolah. JPM IAIN Antasari, 1(2): 73-94

Nugroho, M. H. (2018). Penerapan Model Pembelajaran Realistic Mathematics Education ( RME) untuk Meningkatkan Motivasi dan Prestasi Belajar Matematika Materi Statistika Pada Peserta Didik Kelas XI TP3RP SMK Negeri 1 Kendal Tahun Pelajaran 2015 / 2016. Journal of Mathematics Education IKIP Veteran Semarang, 2(2), 213-223

Rostika, D. (2018). Pembelajaran Volume Bangun Ruang Melalui Pendekatan Konstruktivisme untuk Siswa Sekolah Dasar. Jurnal Pendidikan Dasar. (9)

Rosyada, T. A., Sari, Y., \& Cahyaningtyas, A. P. (2019). Pengaruh Model Pembelajaran Realistic Mathematics Education ( RME ) Terhadap Kemampuan Pemecahan Masalah Matematika Siswa Kelas V. Jurna; IImiah Pendidikan Dasar, 6(2), 116-123.

S, K., \& Taggart, M. (1992). The Action Research Planner. Victoria: Deakrin University.

Sanaky, Hujair AH. (2011). Media Pembelajaran. Yogyakarta: Kakaba

Sari, N. W., Wahyudi, Triyono. (2016). Penerapan Model Realistic Mathematics Education dengan Media Konkret dalam Peningkatan Pembelajaran Pecahan Kelas IV SDN 1 Gunungmujil Tahun 2015/2016. Kalam Cendekia, 4(2): 172 - 178

Shoimin, A. (2014). 68 Model Pembelajaran Inovatif dalam Kurikulum 2013. Yogyakarta: ArRuzz Media

Soraya, F., Cahyana, U., \& Yurniwati. (2018). Penerapan Pendekatan Realistic Matematics Education ( RME) Untuk Meningkatkan Kemampuan Berpikir Kreatif Pokok Bahasan Pecahan Pada Siswa Kelas IV SDN Rawajati 06 Pagi. JPSD, 4(2), 87-94. https://doi.org/http://dx.doi.org/10.26555/jpsd

Sumantri, M. S. (2015). Strategi Pembelajaran Teori dan Praktik Di Tingkat Pendidikan Dasar. Jakarta: Raja Grafindo Persada.

Suprijono, A. (2011). Cooperative Learning Teori dan Aplikasi PAIKEM. Yogyakarta: Pustaka Pelajar

Susanto, A. (2013). Teori Belajar \& Pembelajaran di Sekolah Pembelajaran. Jakarta: Kencana. 
Zulkarnain, D., Syarif, AS., Joharman, Rokhmaniyah. (2019). Penerapan pendekatan saintifik dengan media konkret dalam peningkatan kemampuan memecahkan maslaah pada matematika tentang bangun ruang pada siswa kelas IV SDN 2 Kelapa Sawit tahun ajaran 2017/2018. Kalam Cendikia Jurnal IImiah Kependidikan, 7(2): 2338-9400. 